Review

\title{
Superoxide Dismutases in Eukaryotic Microorganisms: Four Case Studies
}

\author{
Alvaro de Obeso Fernandez del Valle (D) and Christian Quintus Scheckhuber*(D)
}

Citation: de Obeso Fernandez del Valle, A.; Scheckhuber, C.Q.

Superoxide Dismutases in Eukaryotic Microorganisms: Four Case Studies. Antioxidants 2022, 11, 188. https:// doi.org/10.3390/antiox11020188

Academic Editor: Ehab H Sarsour

Received: 16 December 2021

Accepted: 16 January 2022

Published: 19 January 2022

Publisher's Note: MDPI stays neutral with regard to jurisdictional claims in published maps and institutional affiliations.

Copyright: (C) 2022 by the authors. Licensee MDPI, Basel, Switzerland. This article is an open access article distributed under the terms and conditions of the Creative Commons Attribution (CC BY) license (https:// creativecommons.org/licenses/by/ $4.0 /)$.
Departamento de Bioingeniería, Escuela de Ingeniería y Ciencias, Tecnologico de Monterrey, Ave. Eugenio Garza Sada 2501, Monterrey 64849, Mexico; adeobeso@tec.mx

* Correspondence: c.scheckhuber@tec.mx

\begin{abstract}
Various components in the cell are responsible for maintaining physiological levels of reactive oxygen species (ROS). Several different enzymes exist that can convert or degrade ROS; among them are the superoxide dismutases (SODs). If left unchecked, ROS can cause damage that leads to pathology, can contribute to aging, and may, ultimately, cause death. SODs are responsible for converting superoxide anions to hydrogen peroxide by dismutation. Here we review the role of different SODs on the development and pathogenicity of various eukaryotic microorganisms relevant to human health. These include the fungal aging model, Podospora anserina; various members of the genus Aspergillus that can potentially cause aspergillosis; the agents of diseases such as Chagas and sleeping disease, Trypanosoma cruzi and Trypanosoma brucei, respectively; and, finally, pathogenic amoebae, such as Acanthamoeba spp. In these organisms, SODs fulfill essential and often regulatory functions that come into play during processes such as the development, host infection, propagation, and control of gene expression. We explore the contribution of SODs and their related factors in these microorganisms, which have an established role in health and disease.
\end{abstract}

Keywords: Acanthamoeba; Aspergillus; development; pathogenicity; Podospora anserina; reactive oxygen species; superoxide dismutase; Trypanosoma

\section{Introduction}

Superoxide dismutases (SOD) are antioxidant metalloenzymes that dismutate $\mathrm{O}_{2}{ }^{-}$into molecular oxygen and hydrogen peroxide $\left(\mathrm{H}_{2} \mathrm{O}_{2}\right)$, thus, eliminating superoxide radicals. They are key players in defending cells from reactive oxygen species (ROS) during an infection of pathogens [1]. ROS, like superoxide, hydrogen peroxide, hydroxyl radicals, and singlet oxygen, among others, are usually toxic to the cell in elevated concentrations because of their high reactivity with biologically relevant molecules, e.g., proteins, nucleic acids, and lipids. However, in physiological concentrations, some of them are also important regulators of cellular signaling processes. Oxidative stress and its careful management are also important as it is one of the most common means of defense employed by the immune system when combating invading pathogens. As such, ROS are components of the direct and indirect antimicrobial immune response [2]. Furthermore, SODs can be regarded as a crucial defense against pathogens that survive attacks by the immune system of the host during an infection. Therefore, they tend to be the ideal drug target for different therapies [3]. In evolutionary terms, SODs show little structural homology, indicating the convergent evolution of this group of enzymes [4,5]. SODs even have different functions depending on their location within the cell and the organism.

In this review, we provide an overview of SODs from four different microbial eukaryotes: Podospora anserina, Aspergillus spp., Trypanosoma spp., and Acanthamoeba spp. Our objective is to present several examples of microorganisms important to human health, in which research on SODs has unveiled important insights into their developmental processes or on other fundamental biological processes. The filamentous ascomycete P. anserina 
serves as a model for aging while the other organisms are mostly pathogenic. Various species of Aspergilli are grouped and discussed in one section. We also include data on the protists, Trypanosoma spp. and Acanthamoeba spp. We aim to provide a useful overview that aids the reader in understanding the state of knowledge and the opportunities for research regarding SODs and microbial diversity (Figure 1). At this point we would like to note that the SOD nomenclature is not standardized across the literature, and our work reflects this fact. In naming SODs, we generally use the nomenclature found in the references.

\section{Superoxide Dismutase (SOD) in Eukaryotic Microorganisms}

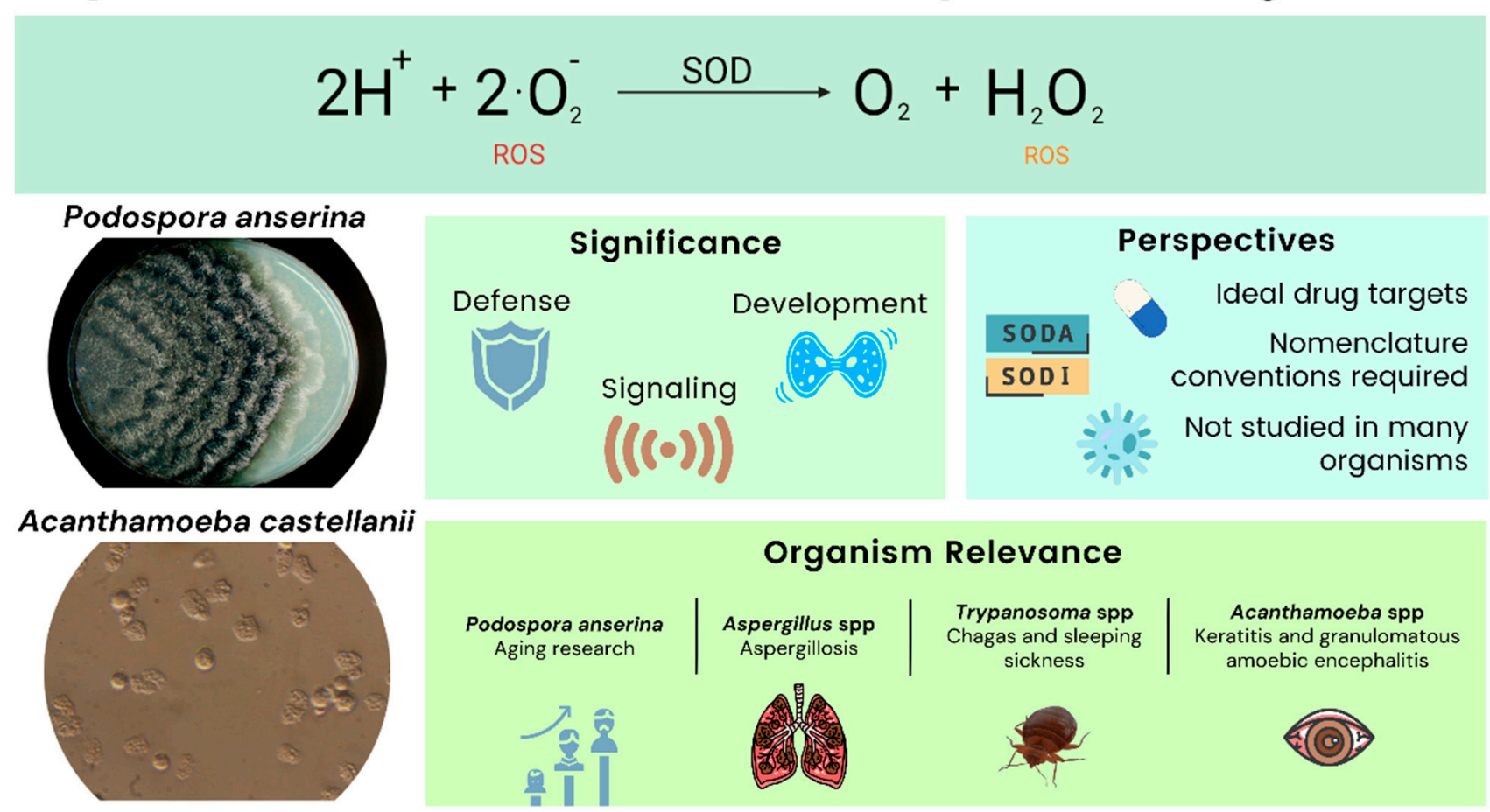

Figure 1. Overview of the article and the significance of SODs in eukaryotic microorganisms.

\section{Fungi}

In this section, the findings on oxidative stress in general, and SODs in particular, from a variety of fungi are reported. Although not a pathogen, research on $P$. anserina shows an impact on human health and disease by its use as a valuable model for studying the process of biological aging. A variety of Aspergillus species are being reviewed, as oxidative stress and antioxidant defense are the key regulators for the pathogenicity of most of these molds.

\subsection{Podospora anserina: A Model System for Biological Aging}

Biological aging is defined as the continuous loss of vitality and viability, with a concomitant increase in morbidity and mortality [6]. Although there have been tremendous efforts to understand the aging process, there is still no consensus on how aging and its unwanted 'side-effects' can be reduced or countered. Rather, simple model systems have been utilized to foster our understanding of how processes, such as senescence and aging, mechanistically work. Fungi, for example, are attractive organisms on which to study the time-dependent changes that lead, ultimately, to organismal death $[7,8]$. In addition to the unicellular baker's yeast (Saccharomyces cerevisiae), a considerable effort has been invested into characterizing aging at the molecular and cellular levels in the filamentous ascomycete, P. anserina, which is a close relative of the more well-known Neurospora crassa [9-12]. Among the studied pathways, the formation and detoxification of harmful ROS in P. anserina are particularly well-characterized $[13,14]$. According to the Free Radical Theory of Aging, ROS are causal agents of the aging process $[15,16]$. Although $P$. anserina is an obligate aerobe, 
mitochondrial defects are not necessarily lethal. In addition to the conventional complex IV (Cytochrome $c$ oxidase, COX), the fungus can use an alternative oxidase (AOX) for maintaining its viability in case COX activity becomes compromised [17]. AOX-dependent respiration was found to lead to the decreased production of ROS in plants and fungi [18,19]. Supporting this line of evidence is the observation that numerous long-lived mutants of P. anserina utilize AOX, but not COX, as terminal oxidase $[17,20]$. In this section, we will focus on the role of SODs on P. anserina development (Figure 2).

\section{$P$. anserina SODs}

\begin{tabular}{|c|c|c|c|c|c|c|}
\hline & PaSOD1 & & PaSOD2 & & PaSOD3 & Name \\
\hline$\rightarrow$ & CuZnSOD & $\rightarrow$ & MnSOD & $\rightarrow$ & MnSOD & Type \\
\hline$\rightarrow$ & Cytoplasm* & $\rightarrow$ & Perinuclear ER & $\rightarrow$ & Mitochondria & Localization \\
\hline & Not available & & Not available & & $\begin{array}{l}\text { Reduced } \\
\text { lifespan }\end{array}$ & Overexpression \\
\hline$\rightarrow$ & Not available & & Not available & 1 & $\begin{array}{l}\text { No effect on } \\
\text { aging }\end{array}$ & Deletion \\
\hline$\rightarrow$ & $\begin{array}{l}\text { Effect on aging } \\
\text { context-depending }\end{array}$ & & $\begin{array}{l}\text { No activity in } \\
\text { mutant grisea }\end{array}$ & 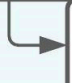 & $\begin{array}{c}\text { Deletion increases } \\
\text { autophagy }\end{array}$ & Remarks \\
\hline
\end{tabular}

Figure 2. Podospora anserina SOD overview. ${ }^{*}$ Further cellular localizations such as intermembrane space of mitochondria are likely. Overexpression and deletion denote genetic manipulations of the corresponding SOD-encoding genes. ER: endoplasmic reticulum.

\subsubsection{PaSOD1: A Differentially Regulated CuZnSOD in Certain Long-Lived Mutants}

Two long-lived $P$. anserina mutants, that display interesting differences regarding their SOD activity profiles, will be briefly discussed here. The findings show that, depending on the genetic context, these enzymes might be potentially linked to a lifespan extension. SOD activity was assessed in the mutants, grisea and ex1, and was compared to the wild type (WT), which exhibits a normal lifespan $[17,21]$. In the WT, the activity of the mostly cytoplasmic CuZnSOD, PaSOD1, (Figure 2) increased strongly with age, whereas the activity of PaSOD2, a MnSOD which is either ER-associated or secreted [22], decreased [17]. The mutant ex1, in which AOX was induced due to a deletion in the mtDNA that led to the loss of the CoI gene (encoding the first subunit of COX), seemed to exclusively employ PaSOD1 [21]. In mutant grisea, a gene encoding a copper-modulated transcription factor (GRISEA) is functionally inactivated by mutation [23]. This mutant experienced severely depleted cellular copper levels [24]. Therefore, the activity of copper-containing proteins, such as COX and PaSOD1, is almost undetectable [21,25]. Importantly, putative target genes of the transcription factor GRISEA are, at most, very weakly expressed. Among these is $P a C t r 3$ (encoding a high-affinity copper transporter of the plasma membrane), which contributes to the severely reduced copper levels in grisea. In the WT, the differential activity of PaSOD1 pointed to a redistribution of cellular copper during aging where the amount of available copper in the cytoplasm increased. This is an example of a clear developmental regulation of PaSOD1 activity at the protein level.

In addition, PaSOD1 seems to play a crucial role in extension of the lifespan of the PaCox17::ble mutant [26]. In this mutant, the putative copper chaperone, PaCOX17, was deleted by gene replacement. The mutant displays an increased lifespan compared to the WT; even after 320 days, 40 out of the 60 cultures were still alive, whereas WT isolates have 
a lifespan of two to three weeks. PaSOD1 levels are highly upregulated in PaCox17::ble, suggesting an improved defense against superoxide anions [26].

Zintel et al. determined that the size of PaSOD1, through an in silico analysis, was $15.8 \mathrm{kDa}$ [22]. Furthermore, PaSOD1 possesses two conserved CuZnSOD signatures. A predominantly cytoplasmic localization was revealed by the construction of a strain that synthesizes PaSOD1::GFP [22].

\subsubsection{PaSOD2: The Enigmatic MnSOD Is Inactivated in the Long-Lived Mutant grisea}

Not all SODs are characterized equally in P. anserina. Here, PaSOD2 is introduced, which offers interesting perspectives for future research to elucidate its potential roles in the developmental processes of $P$. anserina, such as aging.

PaSOD2 has an apparent molecular weight of $26.8 \mathrm{kDa}$ and it contains putative manganese/iron binding motifs [22]. Originally, PaSOD2 was reported to represent a mitochondrial SOD [21,25], although it lacks a clear mitochondrial targeting sequence [22]. Later work showed that PaSOD2 is present in the perinuclear endoplasmic reticulum [22] (Figure 2). The role of a mitochondrial SOD is taken by PaSOD3 [22], which will be discussed below.

As mentioned previously, PaSOD2 activity decreases during aging in P. anserina WT strains [17]. PaSod 2 was originally thought to be a putative target gene of the copper-modulated transcription factor, GRISEA, because it is not detected in isolates of the mutant [17]. Due to the redistribution of cellular copper during the aging of P. anserina, GRISEA was supposed to be inactivated, leading to transcriptional inactivation of $\mathrm{PaSod} 2$ [21]. Later research using transcriptional profiling showed that PaSod2 was transcribed at WT levels in mutant grisea when copper was added to the growth medium; thus, it is not a target gene of GRISEA [27].

2.1.3. PaSOD3: Increasing the Content of This Mitochondrial MnSOD, but Not Its Ablation, Has Effects on Aging

This SOD is, by far, the best studied of the three identified family members of P. anserina (Figure 2). Mutants in which PaSod3 levels were experimentally modulated revealed some unexpected findings, while cleary illustrating that PaSOD3 is linked to other important surveillance and quality control systems in P. anserina. PaSOD3 might also influence several processes by modulating ROS levels (superoxide anion and hydrogen peroxide) that are required for signaling, underscoring the role of ROS as cellular messengers.

PaSOD3 constitutes a mitochondrial SOD with a deduced molecular weight of $25.5 \mathrm{kDa}$. The enzyme contains a putative mitochondrial targeting sequence and was experimentally demonstrated to reside in mitochondria [22]. The impact of PaSOD3 on aging was studied by utilizing mutants in which PaSod3 was either constitutively overexpressed or deleted [22] $\triangle \mathrm{PaSod} 3$ strains were hypersensitive to compounds that generated superoxide anions, such as paraquat, which was expected. In contrast, the sensitivity to hydrogen peroxide was not altered in $\triangle P a S o d 3$. However, the overexpression of $\mathrm{PaSod} 3$ led to a significant growth reduction compared to the WT control, even without any additional stressors. Unexpectedly, these strains were more sensitive to both paraquat and hydrogen peroxide when these compounds were added to the growth medium [22]. Regarding the aging process, $\triangle$ PaSod3 did not show any significant differences compared to the WT control. On the other hand, PaSod 3 overexpressors were short-lived when grown under standard conditions, reaching only around $75 \%$ of the median lifespan of the WT [22]. This can be explained, firstly, by the protein levels of the peroxiredoxin PaPRX1, a mitochondrial peroxidase that detoxifies hydrogen peroxide which was strongly reduced in PaSod3 overexpressors, suggesting a compromised defense against ROS. Secondly, several proteins responsible for the quality control of mitochondria, such as matrix proteases PaCLPP and PaLON, were almost absent, or they exhibited altered protein patterns, due to their incomplete processing or degradation, respectively [22]. Thirdly, the mitochondrial heat shock protein PaHSP60 was clearly upregulated and proteolytically activated in the PaSod3 overexpressing strains [22] The authors suggest that the elevated PaSOD3 levels led to the generation of high doses 
of hydrogen peroxide in mitochondria, which was subsequently converted to the highly reactive hydroxyl radical. The latter is formed by Fenton chemistry involving hydrogen peroxide and various metal ions and it has a highly destructive potential due to its extremely high reactivity with lipids, nucleic acids, and proteins [28].

To better understand the phenotypic effects of the increased PaSod3 expression, a modeling strategy was employed that supported the hypothesis that excess hydrogen peroxide generated by PaSOD3 was responsible for the damaging effects [29]. The computational studies suggested that the levels of the PaSOD3 cofactor, $\mathrm{Mn}^{2+}$, were elevated by a factor of 80 in the PaSod 3 overexpressors. This result led to a study of the role of manganese supplementation of the growth medium of the WT and the PaSod 3 overexpressors on phenotypic parameters [30]. Interestingly, the supplementation of the growth medium with $\mathrm{MnSO}_{4}$, even in small amounts $(20 \mu \mathrm{M})$, led to a reversion of the PaSod3_OEx mutant phenotype. In addition to showing WT-like growth rates, the PaSod3 overexpressors had restored the formation of aerial hyphae and fertility. Regarding aging, $\mathrm{MnSO}_{4}$ concentrations of $80 \mu \mathrm{M}$ allowed the PaSod3_OEx strains to reach median lifespans indistinguishable from those of the WTs [30].

Importantly, the quantification of the total SOD activity (PaSOD1, PaSOD2 and PaSOD3) demonstrated no significant differences in whole cell extracts or isolated mitochondria, regardless of whether Mn was added to the growth medium or not. The authors concluded that a general limitation of manganese on SOD activity in PaSod3 overexpressors did not occur [30].

However, in contrast to the WT, the Mn-supplemented PaSod3 overexpressors demonstrated elevated levels of peroxidase and catalase activities in addition to the upregulated protein levels of the peroxiredoxin, PaPRX. Further results suggested that a hitherto unknown Mn-dependent protein contributed to an improved degradation rate of hydrogen peroxide [30].

PaSOD3 protein levels were shown to be controlled by the protein, PaRCF1 [31]. PaRCF1 belongs to the HIG1 ('hypoxia-inducible gene 1') family of proteins, which play an important role in the assembly and organization of the mitochondrial respiratory chain [32]. A deleted mutant of PaRcf1, $\triangle P a R c f 1$, contains only a fraction of PaSOD3 proteins (approximately $20 \%$ ) compared to the WT, but its activity appears not to be affected [31]. However, $\triangle P a R c f 1$ is hypersensitive to the addition of the redox cycler, paraquat, into the medium in comparison to the WT. Additionally, this mutant fails to maintain a normal growth rate, is sterile, and is marked by a decreased median lifespan. It is important to note that in $\triangle P a R c f 1, P a S O D 3$, as well as other factors of maintenance and cellular quality control decreased, e.g., PaLON, PaPRX and PaCLP [31]. Thus, the altered phenotype of $\triangle P a R c f 1$ is likely the result of several deficiencies.

As mentioned above, the signaling function of ROS is altered in PaSod3 deletion strains [30]. It is known that ROS are modulators of various cellular processes; among these is the controlled cellular 'self-eating', or autophagy [33,34]. Usually, ROS are activators of autophagy, which acts as a system to assist in maintaining cellular homeostasis [35]. It was shown that the 'unexpected healthy phenotype' of $\triangle \mathrm{PaSod} 3$ was due to the induction of autophagy (Figure 2) [36]. The authors demonstrated this by analyzing the number of autophagosomes using the marker Gfp-PaAtg8. These increased, even in juvenile stages. Increased autophagy (especially mitophagy) is important for $\triangle P a S o d 3$ survival because the $\triangle$ PaSod3 $\triangle$ Paatg1 double knockout strain reveals severe phenotypic deficiencies, such as reductions in both the growth rate and lifespan [36].

SODs are enzymes that degrade superoxide anions. However, the generation of superoxide anions is an important process for growth and development in fungi. P. anserina and many other organisms express genes that encode plasma membrane NADPH oxidases, which are sources of superoxide production [37,38].

It was found that genes encoding NADPH oxidases (Nox) are exclusively present in the genomes of multicellular organisms, regardless of their phylogenetic origin, pointing to a role of controlled superoxide production in differentiation processes [39]. Deactivating 
the $P$. anserina gene, PaNox1, leads to several defects, such as the reduced pigmentation of the mycelium, the insufficient formation of aerial hyphae and, most importantly, the compromised formation of perithecia (fruiting bodies). PaNOX1 functions in cellular signaling upstream of the mitogen-activated protein kinase kinase kinase (MAPKKK), PaASK1 [40]. Meanwhile, the deletion of PaNox2, a second NADPH oxidase isoform in $P$. anserina, demonstrates that this gene is essential for the germination of ascospores [40]. In summary, the regulated secretion of superoxide anions and peroxide during the life cycle is controlled by proteins, including PaNOX1, PaNOX2 and PaASK1 [40].

Enzymes such as PaSOD2 are potentially secreted, degrading superoxide anions, thereby modulating the $\mathrm{O}_{2}{ }^{-}$-mediated developmental signaling, although, for now, this is speculative and requires further investigation.

The work on the role of SODs in the developmental process of P. anserina firmly positions these proteins as crucial components of an elaborate network, controlling several vital processes, such as growth, fertility, the intracellular communication of biological quality control pathways and, ultimately, aging.

\subsection{Aspergillus spp.: The Often Pathogenic Fungi Affecting Human Health}

The genus Aspergillus contains several hundred members. Most of them have a cosmopolitan distribution. Many species of this genus are known for their pathogenicity, e.g., A. fumigatus and A. flavus. Others display only mild pathogenicity and are of industrial importance, such as $A$. niger, $A$. oryzae, and $A$. terreus. A. nidulans is a valuable model organism for studying eukaryotic cell biology.

\subsubsection{A. fumigatus: One of the Most Important Fungal Pathogens}

A. fumigatus is one of the best characterized fungal pathogens. In the environment, it plays a crucial role in the recycling of carbon and nitrogen. Due to its abundant sporulation, it releases a huge quantity of conidia into the air that is potentially problematic for people with a compromised immune system. Aspergillosis symptoms first begin in the lungs. In severely predisposed individuals, any organ can be targeted [41]. A. fumigatus is "the most important opportunistic human pathogen among phylogenetically closely related aspergilli" [42]. SOD research using A. fumigatus has revealed several important aspects on how these enzymes co-modulate pathogenicity. Several key findings are outlined below.

The A. fumigatus genome encodes four putative SODs: AfSOD1p, a cytoplasmic CuZnSOD; AfSOD2p, a mitochondrial MnSOD; AfSOD3p, a cytoplasmic MnSOD; and AfSOD4p, which displays a MnSOD domain at its C-terminus [43].

The genes encoding AfSOD1p and AfSOD2p are strongly expressed in A. fumigatus conidia. In contrast, AfSOD3p is found mostly in the mycelium. Although the gene encoding AfSOD4p is only weakly expressed, its deletion is lethal to the fungus. However, it remains to be experimentally shown as to whether AfSOD4p is a bona fide SOD or not [43]. Research showed that the decreased resistance to temperature stress and the ROSgenerating menadione are the hallmarks of AfSOD1 and AfSOD2 deletion. The construction of a triple deletion mutant, $\triangle A f S O D 1-3$, resulted in a complex phenotype. The deletion strains were very sensitive to menadione and were killed by the macrophages in the alveoli of immunocompetent mice. Unexpectedly, virulence, per se, was not distinguishable from the control parental strain in immunocompromised mice [43]. Copper insertion is a critical step for CuZnSOD maturation. In baker's yeast, this step is mediated by the copper chaperone, Ccs1p [44]. Recently, the role of the Ccs1p ortholog from A. fumigatus has been studied in detail [45]. The resulting mutant of a deletion of $\operatorname{ccs} A$ was characterized by the elevated accumulation of ROS and a higher degree of sensitivity to oxidative stress. Importantly, the conserved CXC motif was essential for the interaction between CcsA, SODA, and the adaptation to oxidative stress. SODC, a MnSOD, complemented the defects exhibited by $\operatorname{ccs} A$ or $\operatorname{sod} A$ deletions, if overexpressed, or when $\mathrm{Mn}^{2+}$ was added to the growth medium [45]. Interestingly, the abrogation of the CcsA-SODA complex did not lead to an altered virulence of the fungus. 
In addition to building blocks of the cell wall, such as galactomannan, chitin synthetases, and immune response modulators ( $\operatorname{rodA} / \mathrm{hyp} 1$ and pksP/alb1), several proteins mediating oxidative stress defense have been implicated in pathogenicity, e.g., catalases (Cat1p and Cat2p) and SODs (MnSOD and CuZnSOD) [46].

In A. fumigatus, the expression of genes encoding SODs were found to be controlled by the regulator of the G-protein signaling protein, $\mathrm{RgsC}$, which is highly conserved in ascomycetes [47]. Furthermore, the deletion of the $\mathrm{rgsC}_{\mathrm{s}}$ gene led to a pleiotropic phenotype. The described hallmarks include compromised growth, asexual development, the reduced ROS tolerance of conidia, and the decreased virulence in the wax moth [47]. The phenotype of the mutant could be related to the compromised ROS signaling because the gene expressions and enzymatic activities of catalases and SODs were severely decreased [47].

Under the conditions of iron-deprivation, A. fumigatus was found to transcriptionally upregulate genes encoding CuZnSOD and other iron-independent antioxidant proteins $[42,48]$. This is not unexpected, because several important antioxidant enzymes depend on the levels of available iron as a cofactor, such as catalases and heme peroxidases [49]. Conditions of low iron and oxidative stress are encountered by A. fumigatus when it colonizes the human body [42]. It was found, through a transcriptome analysis, that iron deprivation increases oxidative stress susceptibility and pharmacologically targeting these iron-independent antioxidant defense systems might offer the potential to effectively combat fungal infections. Purified CuZnSOD from A. fumigatus has been successfully employed in the detection of aspergillosis because it has a high level of immune reactivity to the sera of patients [50].

\subsubsection{A. flavus: Spoiling Food by Toxin Production}

A. flavus is a human pathogen that can cause aspergillosis. Additionally, it can spoil several food sources such as cereal grains, legumes, and tree nuts. The consumption of contaminated feed can increase the chance for liver cancer because $A$. flavus produces the mycotoxin, Aflatoxin B1 [51]. Aflatoxin B1 is one of the most dangerous mycotoxins. Several results point towards a connection between aflatoxin synthesis and the production and detoxification of ROS. Aflatoxin B1 toxicity can be ameliorated by piperine, which is usually found in certain peppers [52,53]. It was shown that piperine not only downregulated the set of genes that led to aflatoxin toxicity, but it also positively influenced the concentrations of antioxidants in A. flavus [54]. Several genes that encode antioxidant proteins, including members of the SOD family, were significantly upregulated upon piperine treatment. There is a clear correlation between levels of ROS and the capability of A. flavus to synthesize aflatoxin [55-57]. However, a study showed that the superoxide generator, menadione, was capable of decreasing aflatoxin production in A. flavus NRRL3357 [58]. In this study, SOD activity decreased in the presence of menadione. A study aimed at deciphering the interplay between oxidative stress, superoxide activity, and aflatoxin biosynthesis found that the redox cycler and the superoxide generator, paraquat, at low concentrations, inhibited aflatoxin production [59]. The transcription of the regulator gene aflR and the aflatoxin biosynthetic cluster genes were downregulated by the paraquat treatment. Although the addition of purified CuZnSOD to the culture medium counteracted the paraquat-mediated increase in superoxide production by A. flavus, aflatoxin biosynthesis was not restored, because the CuZnSOD protein itself displayed an inhibitory effect [59]. By contrast, cytosolic and mitochondrial superoxide production was capable of downregulating aflatoxin production by decreasing aflR expression. The mechanism by which supplementing CuZnSOD to the growth medium resulted in a reduction of aflatoxin formation is not yet clear, but it likely does not involve the detoxification of superoxide anions [59].

A. flavus, being an opportunistic pathogen, was found to be susceptible to the puroindoline B (PINB) protein [60]. PINB is capable of severely compromising the fungus, evidenced by withering of the mycelium, the damage to cell membranes, and the disruption of the tricarboxylic acid cycle. It is noteworthy that in addition to catalase, SOD activity was found to be reduced. As a result, the GSH/GSSG ratio was reduced and the levels of ROS 
were elevated [60]. These results demonstrate that antioxidant enzymes are among the best targets for controlling pathogens such as A. flavus.

A variety of antifungal peptides for improving food safety have been evaluated [61]. The expression of MnSOD was found to be affected at the transcript level, as evidenced by RT-qPCR. Intracellular levels of ROS decreased in the fungi subjected to the peptides. ABTS and DPPH assays were used to demonstrate that the peptides harbor antioxidant activities. The expression of the genes in the aflatoxin biosynthesis cluster was downregulated, as well as the conidiation of the mycelia [61]. In summary, the analyzed antifungal peptides are promising inhibitors of toxicity from Aspergilli, such as A. flavus.

MnSOD was found to be important for $A$. flavus when it exploits maize as a source of nutrients [62]. Four trophic conditions were analyzed in this work: (a) Czapek Dox (CD) medium in flasks, (b) Czapek Dox (CD) medium in flasks containing injured maize kernels within a closed dialysis tube, (c) autoclaved maize kernels, and (d) maize ears in the field. Under all tested conditions, the mutant without MnSOD was shown to grow slower than the WT control. Under growth condition (d), aflatoxin production was significantly decreased [62]. The authors hypothesize that the ROS produced at the point of contact between $\Delta$ sod and its host severely affected the fitness of this mutant. Furthermore, the increased ROS production in the mitochondria of the mutant might cause molecular damage to essential components of the TCA cycle, such as aconitase. This might force the mutant to reroute its resources to maintain growth and antioxidant defense so that it can no longer adequately support the biosynthesis of aflatoxin [62].

\subsubsection{A. parasiticus: An Important Aflatoxin Producer}

A. parasiticus, like A. flavus, is known as a potent producer of aflatoxin [63]. The relationship between aflatoxin biosynthesis and cellular ROS levels was investigated in detail in the A. parasiticus strain, SU-1, and its aflatoxin-negative mutant, AFS10, in detail [64]. SU-1 handled intracellular ROS much more effectively than AFS10, which is likely due to the efficient transcriptional activation of five genes encoding members of the SOD family. However, supplementing the growth medium of AFS10 with aflatoxin led to a noticeable reduction of ROS without changing the expression of the genes encoding SODs. In conclusion, aflatoxin biosynthesis aids $A$. parasiticus in coping with oxidative stress. This occurs dependent of the aflR regulator gene and the mycotoxin itself [64]. It would be interesting to analyze whether $A$. flavus demonstrates a similar behavior.

\subsubsection{A. terreus: The Emerging Pathogen of Human Health}

In contrast to several other members of the genus Aspergillus, such as the aforementioned A. fumigatus, the mold A. terreus is not as common an agent of aspergillosis [65]. However, in recent years, the fungus is increasingly receiving attention because the cases in which it causes disease are steadily increasing [65]. A. terreus shows high resistance to the antibiotic, amphotericin $B$, which is problematic for the treatment of infections. However, there are also $A$. terreus isolates that do display a susceptibility to amphotericin B. Jukic et al. compared pathogenicity between an amphotericin B-resistant and a susceptible A. terreus strain [66]. Resistant strains responded much more effectively to amphotericin B treatment than sensitive strains, shown by their strongly induced transcript levels of Sod 2 and the gene encoding catalase. Importantly, inhibiting these antioxidant proteins confers a susceptibility to amphotericin B [66]. Therefore, enzymes of the oxidative stress response should be regarded as interesting targets for treating infections by $A$. terreus and, possibly, by other Aspergilli as well.

\subsubsection{A. nidulans: A Valuable Model System for the Study of Eukaryotic Cell Biology}

Aspergillus spp. are capable of producing enormous quantities of conidia. This ability is linked to several factors involving mitochondrial function. ROS and the modulation of their cellular levels by antioxidant enzymes are integrated into the network that controls the 
production of conidia. Due to the ease of constructing genetically altered strains, A. nidulans is highly valuable for the study of developmental processes, such as conidiation.

Here, we give an example in which the potential targets for counteracting asexual reproduction, by focusing on the characterization of mitochondrial quality control systems, were identified [67]. The components were $\operatorname{aod} A$, an alternative oxidase in the mitochondrial respiratory chain; $d n m A$, a dynamin-like protein involved in organelle fission; pimA, a mitochondrial LON protease; and the mitochondrial SOD, MnSOD. The mutant phenotypes of $A$. nidulans with deletions and overexpressions of these genes were compared to experimental data from P. anserina research. Importantly, many differences in phenotypic aspects were detected between $A$. nidulans and P. anserina [67]. For example, several of the phenotypes were only observed sporadically, or were distributed without an emerging pattern among the gene overexpression and deletion mutants. The only common denominator was a clearly impaired amount and viability of conidiospores. Importantly, the decreased production and viability of conidiospores was observed in all gene deletion mutants, pointing out the clear role of mitochondrial functionality in asexual reproduction. One of the main mitochondrial differences is that in P. anserina, mtDNA is subject to gross reorganizations during aging [10]. Several of the aforementioned gene orthologs might, thus, affect mitochondrial biology differently in P. anserina than in A. nidulans. Lastly, it should be kept in mind that both species are not extremely closely related, with $P$. anserina belonging to the taxonomic unit of Sordariomycetes and A. nidulans to Eurotiomycetes, which might also help to explain at least some of the observed differences.

\subsubsection{A. glaucus: An Interesting Platform for the Production of Pharmaceuticals}

There is a constant demand to isolate improved and more stable enzymes that have superior properties, with SODs being no exception. One example is the cold-adapated A. glaucus that enabled the isolation of an SOD with such properties. Among the Aspergilli, A. glaucus is better adapted to more extreme environmental conditions than most of its relatives [68]. For example, A. glaucus strain 363 was reported to contain a cold-adapted $\mathrm{CuZnSOD}$ that is highly active at low temperatures, such as those lower than $10^{\circ} \mathrm{C}$ [69]. This antioxidant could be very useful in the protection of sperm cells in the field of assisted reproductive technology [69]. In addition, A. glaucus produces mycotoxins, such as aspergiolide $\mathrm{A}$, that are being evaluated as potential anti-cancer agents [70].

\section{Protists}

In this section we focus on two different protists. Protists are a very diverse polyphyletic group, and the diversity of SODs demonstrates this fact. For example, in the slime mold Dictyostelium discoideum, SODs serve as starvation signals that are causative of the multicellular stage, and gene overexpression can inhibit multicellularity [71]. In the case of the malaria-causing unicellular protozoan parasite Plasmodium falciparum, Fe-SOD has been suggested as a highly selective target for antiparasitic drugs [72]. Furthermore, SODs and pyruvate have been linked to metronidazole resistance in Entamoeba histolytica, meaning that there could be a link to drug resistance, as it is associated with other forms of stress [73,74]. Several protozoans have Fe-SOD, which are regularly found in prokaryotes, but are also present in archaeal organisms and plants. In evolutionary terms, Fe-SODs are the most ancient SODs [4]. It is important to note that not all protists present SODs, as in the case of the giardiasis-causing flagellate parasite Giardia duodenalis [75,76].

Two different genera were chosen to exemplify the role of SODs in potentially pathogenic protists: Trypanosoma and Acanthamoeba.

\subsection{Trypanosoma spp.: Pathogenic Organisms Responsible for Typanosomiasis}

Trypanosomes are hemoflagellate aerobic protozoans which cause African and American trypanosomiasis, also known as sleeping sickness and Chagas disease, respectively [77]. Trypanosomiasis is listed by the World Health Organization (WHO) as one of seventeen neglected tropical diseases [78]. Trypanosomes have a complex life cycle that includes a 
trypomastigote that lives in insects (depending on the species) and is capable of infecting mammals. Inside mammals, and, therefore, humans, the trypomastigote invades cells and becomes an amastigote that starts dividing. Finally, amastigotes become bloodstream trypomastigotes that lyse the cells and infect new cells. When the infected person comes into contact with another insect, the parasite becomes an epimastigote that survives in the insect's gut [77]. Among the Trypanosoma species, the most relevant are T. cruzi (Chagas disease) and T. brucei (sleeping sickness). However, T. evansi is the causative agent of "surra", an important disease that affects camels, horses, and dogs [79]. Additionally, T. vivax is the most common trypanosome in Africa, and causes animal trypanosomiasis, or nagana disease, in cattle [80,81]. As Trypanosoma can become intracellular parasites, SODs play an important role in their survival as a defense against oxidative stress and are, therefore, ideal therapy targets. Notably, some of the most common enzymes against oxidative stress are catalases and glutathione peroxidase. These are missing from trypanosomatids, making the role of SOD even more important $[82,83]$. Next, we examine the role of SODs in T. cruzi and T. brucei.

\subsubsection{Trypanosoma cruzi: A Causative Agent of Chagas Disease}

Chagas disease, or American trypanosomiasis, is caused by T. cruzi and occurs mainly in Latin America and parts of the United States. T. cruzi is transmitted by triatomine bugs that are also known as kissing bugs. The disease can be asymptomatic, acute, or chronic, and can lead to death [77].

Macrophages produce superoxide toxicity as a first line of defense against T. cruzi [84]. There are several defenses against oxidative stress in T. cruzi. Among them are: arginase, isocitrate dehydrogenase, the glutathione peroxidase-like protein, trypanothione reductase, Fe-SOD, the acetylornithine deacetylase-like protein, Cytochrome $b_{5}$ reductase, and thioldependent reductase [85]. Several SODs have been identified in T. cruzi. The first was an iron-dependent SOD [86]. Soon after, two SODs were cloned and characterized: Fe-SODA and Fe-SODB [87]. Fe-SODA is constitutively expressed, while Fe-SODB is overexpressed during the epimastigote stage [87]. Later, four different SOD activities were characterized in epimastigotes (SOD I, II, III and IV). SODI and SODIII appear to be present as dimers, as the resulting sizes do not match any sequences in the trypanosomatid genome and are mainly cytosolic [88]. Two of these Fe-SOD-encoding genes are found as multiple repeating units across the genome of T. cruzi [87].

T. cruzi produces cytosolic SOD to defend itself from superoxides. An Fe-SOD enriched T. cruzi showed an almost two-fold rate of survival compared to the WT when challenged with macrophages [84]. Fe-SODB can detoxify cytosolic superoxide derived from macrophages, preventing damage and increasing the virulence of T. cruzi [89].

Additionally, SODs have an important role in the Trypanosoma life cycle. SODA plays a role in amastigogenesis, as shown by a $70 \%$ increase in the expression of the gene after 60 min of trypomastigote induction [90]. The increased expression of SODA decreased the number of apoptotic amastigotes. This means it plays a role in survival from antioxidantbased immune responses [91].

Being intracellular pathogens, trypanosomes are highly sensitive to ROS. Therefore, SODs are interesting targets for drug development [92]. T cruzi hosts, transfected with a FeSOD (overexpressed 5- to 8-fold), demonstrated increased sensitivity against trypanocidal agents such as benznidazole and gentian violet, probably due to imbalances in the antioxidant defenses of the parasite [86]. T. cruzi strains that are resistant to benznidazole presented an increased expression of the gene encoding SODA [93]. Benznidazole-resistant strains decreased SODB synthesis and increased that of SODA [94]. SOD inhibition in T. cruzi, by the derivatives of aza-scorpiand-like macrocycles, showed antichagasic properties [95]. Additionally, 1,4-bis(alkylamino)benzo[g]phthalazines 1-4 containing one or two imidazole rings showed an inhibition of the parasite's Fe-SOD and a significant decrease in amastigote and trypomastigote numbers without affecting human Cu-Fe-SOD [96]. Deoxymikanolide is a sesquiterpene lactone that showed decreased SOD activity of up to $40 \%$ after $24 \mathrm{~h}$. 
However, according to the authors, the antiparasitic activity of the deoxymikanolide was more strongly related to a decrease in thiol groups that the sesquiterpene causes. The SOD activity was, therefore, probably related to the damage caused by the intracellular oxidative state [97]. Further examples are the two compounds for the leishmanicidal [1-3]Triazolo[1,5a]pyridinium salt compound that showed trypanocidal effects through the inhibition of Fe-SOD activity [98]. Drug susceptibility may, therefore, be strain-dependent [94].

SODs have been suggested as diagnostic tools against Chagas disease. A study that identified T. cruzi antibodies, using Fe-SOD as the antigen, showed a $99.13 \%$ sensitivity and a 96.01\% specificity for the diagnosis of Chagas disease in 969 Mexican blood donors [99]. Additionally, 1029 individuals were tested in Queretaro, Mexico, through Western blot, ELISA, and indirect haemagglutination for T. cruzi SODs. A seroprevalence value of $8.16 \%$ was obtained, which is higher than those previously reported in Chagas disease endemic regions [100]. Similar experiments were performed to identify T. cruzi antibodies in cats (7.36\% seroprevalence) and dogs (with a seroprevalence ranging from $10.74 \%, 17.1 \%$, and $21.34 \%$, depending on the region and the study) across the Yucatan Peninsula [101-103]. Lastly, a similar study was performed that testd dogs in Tabasco and they presented a $3.36 \%$ serological prevalence in domiciled dogs out of 119 sera [104].

\subsubsection{Trypanosoma brucei: Causative Agent of Sleeping Sickness}

Sleeping sickness, or African trypanosomiasis, is caused by T. brucei gambiense or T. brucei rhodesiense. These parasites cause chronic disease and are transmitted by tsetse flies. Sleeping sickness is fatal without treatment [77].

Four SOD have been identified in T. brucei, three of which are Fe-SODs [105]. The SODs are TbSODA, TbSODB1, TbSODB2, and TbSODC, where Tb refers to the organism. TbSODB1 is mainly cytosolic, while TbSODB2 is mainly glycosomal. TbSODA and TbSODC are mitochondrial [106]. A phylogenetic analysis of 106 SODs indicated that trypanosomatid SODs have been acquired through more than one horizontal transfer event [106].

TbSODB1 plays an important role in the defense against superoxide-inducing drugs, as it has been shown that the deletion of the gene increased its sensitivity to nifurtimox and benznidazole [107] The downregulation of glycosomal TbSODB2 corresponded to an increase in cell death among the population [105]. The aqueous extract of fruit pulp of the African tree Adansonia digitata showed effective trypanocidal effects through the inhibition of SODs against T. brucei in albino rats [108]. Other extracts or compounds studied as potential therapies, using SOD as a target, include: zinc and selenium [109], a-tocopherol [110], and tetradentated pyridine-based manganese complexes such as Cpd2 and Cpd3 [111].

As is the case in T. cruzi, SODs play a role in the life cycle of T. brucei. A type of Fe-SOD was cloned and was identified as playing a crucial role in T. brucei, which is only required in the proliferation stages of the organism to eliminate superoxide radicals produced during this developmental stage [112].

\subsection{Acanthamoeba spp.: The Pathogenic Free Living Amoebae}

Acanthamoeba are free-living amoeboid organisms with a worldwide distribution. They are capable of producing diseases such as granulomatous amoebic encephalitis and Acanthamoeba keratitis [113]. The main species of Acanthamoeba is A. castellanii. As a freeliving organism with pathogenic capabilities, Acanthamoeba must be capable of surviving with different oxidative conditions. SODs in Acanthamoeba have not been extensively researched. However, there are several reviews related to the biology and pathogenicity of Acanthamoeba that have highlighted their importance [114-116].

Two SODs have been identified in Acanthamoeba so far; Fe-SOD (approximately $50 \mathrm{kDa}$ ) and CuZn-SOD (approximately $38 \mathrm{kDa}$ ). These Acanthamoeba SODs are found in the cytoplasm and in the detergent-extractable phase [114,117]. The Fe-SOD is formed by a $2.33 \AA$ single crystal with well-conserved fold and active-site residues [118]. A third mitochondrial Mn-SOD has been related to mitochondrial bioenergetics [119]. 
During phagocytosis, Acanthamoeba produces superoxides, similar to phagocytes. due to a "respiratory burst" of oxidase that aids in the phagocytosis of bacteria $[120,121]$. A. castellanii has superoxide-generating NADPH oxidase that kills and lyses bacteria, similar to $D$. discoideum [122]. This process is comparable to what macrophages employ to lyse and kill bacteria [116]. Acanthamoeba utilizes SODs as an environmental adaptation with antioxidant properties [123]. Acanthamoeba also requires SODs to be able to adapt to oxidative conditions in hosts and to defend itself from oxidative death by immune effector cells [124]. As they act as antioxidants and anti-inflammatory agents, they have been identified as potential virulence factors [117]. SOD activity was shown to be lower in the virulent species of the genus Acanthamoeba, ranging from 40-65 units/mg of protein in non-pathogenic strains, to $21-23$ units/mg of protein in pathogenic strains [125]. Fe-SOD is vital for Acanthamoeba survival, as it helps in the defense against endogenous oxidative stress and oxidative death by immune effector cells. SODs could be targets for chemotherapy and immunodiagnoses [117].

Acanthamoeba shows the plasticity of mitochondrial bioenergetics during batch cultures where the in vitro production of ROS decreases. This high plasticity ensures the survival of high quality cysts under stress-decreasing ROS without altering SOD production [119]. The $26 \mathrm{kDa}$ Mn-SOD activity stayed close to $100 \%$ after $96 \mathrm{~h}$ in a batch culture to protect against ROS production [119].

\section{Perspectives/Conclusions}

The study of SODs plays an important role in comprehending the biology of organisms such as P. anserina, Aspergillus, Trypanosoma, and Acanthamoeba. SODs have been extensively studied in some clades but have been slightly neglected in some regions of the evolutionary tree. We aimed to highlight the potential of these enzymes for studying, understanding, and possibly even controlling these types of organisms. Even though we limit our review to four genera, SODs play an important role in a great variety of microorganisms. Table 1 proposes some literature for the reader who wants to enhance their understanding on the role of SODs in other relevant eukaryotic microorganisms which have not been addressed in the present review.

In general, ROS were viewed for a long time as largely unavoidable toxic by-products of several metabolic pathways. However, as already mentioned in the introduction, it has become clear that they also serve essential functions in regulating metabolism as signaling molecules. Several of the early theories on the causes of organismic aging pointed to ROS as agents of molecular damage, cumulating eventually in pathogenicity and death [126]. However, more recent work, especially from the nematode Caenorhabditis elegans, as well as in rodents, paints a different picture [127]. ROS can be regarded as mediators and coordinators of the stress response systems that become triggered during aging. Among these are the fusion and fission of organelles, such as mitochondria and peroxisomes, the proteolytic degradation of damaged enzymes, and the coordinated removal of compromised organelles (autophagy) [128-130]. Antioxidant enzymes, similar to the SODs in which this contribution is focused, allow the conversion of highly reactive superoxide radicals to become less reactive and more long-lived, for example hydrogen peroxide, which can pass greater distances within the cell [131]. In general, due to their high reactivity, most ROS exist only for a very short time in the crowded environment of the cell, approximately $100 \mathrm{~ns}$ for singlet oxygen, for example [132]. However, similar to hydrogen peroxide, superoxide anions can interact specifically with target enzymes. This has been demonstrated for the soluble form of guanylate cyclase, with which the cGMP-producing activity is inhibited by $\mathrm{O}_{2}{ }^{-}$[133]. As such, SODs not only serve a protective role during cellular life and development, but they are also integrated into elaborate signaling networks. Unraveling these networks is challenging but necessary to understand various biological processes outlined in our review, such as growth, sexual and asexual propagation, metabolite biosynthesis, pathogenicity, and, ultimately, aging. 
Table 1. Selected literature for relevant eukaryotic microorganisms not covered in this review.

\begin{tabular}{ccc}
\hline Organism & Significance & Reference \\
\hline & Protists & {$[71]$} \\
\hline Dictyostelium discoideum & Social slime mold, studies of multicellularity & {$[76]$} \\
Entamoeba histolytica & Pathogen of amebiasis & {$[75]$} \\
Giardia lamblia & Lacks SODs, agent of intestine infection & {$[134]$} \\
Plasmodium falciparum & Pathogen of malaria & {$[135]$} \\
Toxoplasma gondii & Pathogen of toxoplasmosis & {$[136]$} \\
\hline & Fungi & {$[137]$} \\
Penicillium chrysogenum/rubrum & Circadian rhythms, epigenetics, gene silencing, cell polarity & {$[138]$} \\
Pichia pastoris & Antibiotics and enzyme production & {$[44]$} \\
Saccharomyces cerevisiae & Heterologous protein production & {$[139]$} \\
Schizosaccharomyces pombe & Many aspects of basic and applied science & {$[140]$} \\
Sordaria macrospora & DNA damage, repair, and replication & Fruiting body development \\
\hline
\end{tabular}

Additionally, we would like to stress the importance of a standardized nomenclature for naming and distinguishing SODs. Currently, a plethora of naming schemes are being used by the scientific community. Like valuable efforts towards unifying the nomenclature of cell death factors [141], meta- and paracaspases [142], and autophagy-related genes [143], this step is necessary, in our opinion, to avoid confusion when it comes to naming SODs.

Finally, the study of SODs and their potential roles as regulators of developmental processes is limited to a certain set of organisms. Certainly, it could be very valuable to initiate research projects to unravel the importance of SOD activity in organisms that have not received much attention, in this regard, so far.

Author Contributions: Conceptualization, A.d.O.F.d.V. and C.Q.S.; writing—original draft preparation, A.d.O.F.d.V. and C.Q.S.; writing—review and editing, A.d.O.F.d.V. and C.Q.S. All authors have read and agreed to the published version of the manuscript.

Funding: The APC was funded by Tecnológico de Monterrey.

Acknowledgments: We would like to acknowledge Erandi Ortega Barragán for her helpful graphical design contributions.

Conflicts of Interest: The authors declare no conflict of interest.

\section{References}

1. Maurya, R.; Namdeo, M. Superoxide dismutase: A key enzyme for the survival of intracellular pathogens in host. In Reactive Oxygen Species; Ahmad, R., Ed.; IntechOpen Limited: London, UK, 2021.

2. Herb, M.; Schramm, M. Functions of ROS in macrophages and antimicrobial immunity. Antioxidants 2021, 10, 313. [CrossRef] [PubMed]

3. Paiva, C.N.; Bozza, M.T. Are reactive oxygen species always detrimental to pathogens? Antioxid. Redox Signal. 2013, 20, 1000-1037. [CrossRef]

4. Case, A.J. On the origin of superoxide dismutase: An evolutionary perspective of superoxide-mediated redox signaling. Antioxidants 2017, 6, 82. [CrossRef]

5. Landis, G.N.; Tower, J. Superoxide dismutase evolution and life span regulation. Mech. Ageing Dev. 2005, 126, 365-379. [CrossRef]

6. Jazwinski, S.M.; Kim, S. Examination of the dimensions of biological age. Front. Genet. 2019, 10, 263. [CrossRef] [PubMed]

7. Kaeberlein, M. Lessons on longevity from budding yeast. Nature 2010, 464, 513-519. [CrossRef] [PubMed]

8. Bhattacharya, S.; Bouklas, T.; Fries, B.C. Replicative aging in pathogenic fungi. J. Fungi 2021, 7, 6. [CrossRef]

9. Lorin, S.; Dufour, E.; Sainsard-Chanet, A. Mitochondrial metabolism and aging in the filamentous fungus Podospora anserina. Biochim. Biophys. Acta Bioenerg. 2006, 1757, 604-610. [CrossRef]

10. Scheckhuber, C.Q.; Osiewacz, H.D. Podospora anserina: A model organism to study mechanisms of healthy ageing. Mol. Genet. Genom. 2008, 280, 365-374. [CrossRef] [PubMed]

11. van Diepeningen, A.D.; Engelmoer, D.J.P.; Sellem, C.H.; Huberts, D.H.E.W.; Marijke Slakhorst, S.; Sainsard-Chanet, A.; Zwaan, B.J.; Hoekstra, R.F.; Debets, A.J.M. Does autophagy mediate age-dependent effect of dietary restriction responses in the filamentous fungus Podospora anserina? Philos. Trans. R. Soc. B Biol. Sci. 2014, 369, 20130447. [CrossRef]

12. Osiewacz, H.D.; Schürmanns, L. A network of pathways controlling cellular homeostasis affects the onset of senescence in Podospora anserina. J. Fungi 2021, 7, 263. [CrossRef] 
13. Gredilla, R.; Grief, J.; Osiewacz, H.D. Mitochondrial free radical generation and lifespan control in the fungal aging model Podospora anserina. Exp. Gerontol. 2006, 41, 439-447. [CrossRef] [PubMed]

14. Wiemer, M.; Osiewacz, H.D. Effect of paraquat-induced oxidative stress on gene expression and aging of the filamentous ascomycete Podospora anserina. Microb. Cell 2014, 1, 225-240. [CrossRef] [PubMed]

15. Harman, D. Aging: A theory based on free radical and radiation chemistry. J. Gerontol. 1956, 11, 298-300. [CrossRef] [PubMed]

16. Son, J.M.; Lee, C. Aging: All roads lead to mitochondria. Semin. Cell Dev. Biol. 2021, 116, 160-168. [CrossRef] [PubMed]

17. Borghouts, C.; Werner, A.; Elthon, T.; Osiewacz, H.D. Copper-modulated gene expression and senescence in the filamentous fungus Podospora anserina. Mol. Cell. Biol. 2001, 21, 390-399. [CrossRef]

18. Minagawa, N.; Koga, S.; Nakano, M.; Sakajo, S.; Yoshimoto, A. Possible involvement of superoxide anion in the induction of cyanide-resistant respiration in Hansenula anomala. FEBS Lett. 1992, 302, 217-219. [CrossRef]

19. Maxwell, D.P.; Wang, Y.; McIntosh, L. The alternative oxidase lowers mitochondrial reactive oxygen production in plant cells Proc. Natl. Acad. Sci. USA 1999, 96, 8271-8276. [CrossRef]

20. Scheckhuber, C.Q.; Houthoofd, K.; Weil, A.C.; Werner, A.; de Vreese, A.; Vanfleteren, J.R.; Osiewacz, H.D. Alternative oxidase dependent respiration leads to an increased mitochondrial content in two long-lived mutants of the ageing model Podospora anserina. PLoS ONE 2011, 6, e16620. [CrossRef]

21. Borghouts, C.; Scheckhuber, C.Q.; Werner, A.; Osiewacz, H.D. Respiration, copper availability and SOD activity in P. anserina strains with different lifespan. Biogerontology 2002, 3, 143-153. [CrossRef]

22. Zintel, S.; Schwitalla, D.; Luce, K.; Hamann, A.; Osiewacz, H.D. Increasing mitochondrial superoxide dismutase abundance leads to impairments in protein quality control and ROS scavenging systems and to lifespan shortening. Exp. Gerontol. 2010, 45, 525-532. [CrossRef]

23. Osiewacz, H.D.; Nuber, U. GRISEA, a putative copper-activated transcription factor from Podospora anserina involved in differentiation and senescence. Mol. Gen. Genet. 1996, 252, 115-124. [CrossRef] [PubMed]

24. Borghouts, C.; Osiewacz, H.D. GRISEA, a copper-modulated transcription factor from Podospora anserina involved in senescence and morphogenesis, is an ortholog of MAC1 in Saccharomyces cerevisiae. Mol. Gen. Genet. 1998, 260, 492-502. [CrossRef]

25. Borghouts, C.; Scheckhuber, C.Q.; Stephan, O.; Osiewacz, H.D. Copper homeostasis and aging in the fungal model system Podospora anserina: Differential expression of PaCtr3 encoding a copper transporter. Int. J. Biochem. Cell Biol. 2002, 34, 1355-1371. [CrossRef]

26. Stumpferl, S.W.; Stephan, O.; Osiewacz, H.D. Impact of a disruption of a pathway delivering copper to mitochondria on Podospora anserina metabolism and life span. Eukaryot. Cell 2004, 3, 200-211. [CrossRef] [PubMed]

27. Servos, J.; Hamann, A.; Grimm, C.; Osiewacz, H.D. A differential genome-wide transcriptome analysis: Impact of cellular copper on complex biological processes like aging and development. PLoS ONE 2012, 7, e49292. [CrossRef]

28. Wardman, P.; Candeias, L.P. Fenton chemistry: An introduction. Radiat. Res. 1996, 145, 523-531. [CrossRef]

29. Kowald, A.; Hamann, A.; Zintel, S.; Ullrich, S.; Klipp, E.; Osiewacz, H.D. A systems biological analysis links ROS metabolism to mitochondrial protein quality control. Mech. Ageing Dev. 2012, 133, 331-337. [CrossRef] [PubMed]

30. Grimm, C.; Osiewacz, H.D. Manganese rescues adverse effects on lifespan and development in Podospora anserina challenged by excess hydrogen peroxide. Exp. Gerontol. 2015, 63, 8-17. [CrossRef]

31. Fischer, F.; Filippis, C.; Osiewacz, H.D. RCF1-dependent respiratory supercomplexes are integral for lifespan-maintenance in a fungal ageing model. Sci. Rep. 2015, 5, 12697. [CrossRef]

32. Strogolova, V.; Furness, A.; Robb-McGrath, M.; Garlich, J.; Stuart, R.A. Rcf1 and Rcf2, members of the hypoxia-induced gene 1 protein family, are critical components of the mitochondrial cytochrome bc 1 -cytochrome c oxidase supercomplex. Mol. Cell. Biol. 2012, 32, 1363-1373. [CrossRef] [PubMed]

33. Scherz-Shouval, R.; Elazar, Z. ROS, mitochondria and the regulation of autophagy. Trends Cell Biol. 2007, 17, 422-427. [CrossRef] [PubMed]

34. Wang, Y.; Nartiss, Y.; Steipe, B.; McQuibban, G.A.; Kim, P.K. ROS-induced mitochondrial depolarization initiates PARK2/PARKINdependent mitochondrial degradation by autophagy. Autophagy 2012, 8, 1462-1476. [CrossRef]

35. Priault, M.; Salin, B.; Schaeffer, J.; Vallette, F.M.; di Rago, J.P.; Martinou, J.C. Impairing the bioenergetic status and the biogenesis of mitochondria triggers mitophagy in yeast. Cell Death Differ. 2005, 12, 1613-1621. [CrossRef] [PubMed]

36. Knuppertz, L.; Warnsmann, V.; Hamann, A.; Grimm, C.; Osiewacz, H.D. Stress-dependent opposing roles for mitophagy in aging of the ascomycete Podospora anserina. Autophagy 2017, 13, 1037-1052. [CrossRef] [PubMed]

37. Vignais, P.V. The superoxide-generating NADPH oxidase: Structural aspects and activation mechanism. Cell. Mol. Life Sci. 2002, 59, 1428-1459. [CrossRef]

38. Bokoch, G.M.; Knaus, U.G. NADPH oxidases: Not just for leukocytes anymore! Trends Biochem. Sci. 2003, 28, 502-508. [CrossRef]

39. Lalucque, H.; Silar, P. NADPH oxidase: An enzyme for multicellularity? Trends Microbiol. 2003, 11, 9-12. [CrossRef]

40. Malagnac, F.; Lalucque, H.; Lepère, G.; Silar, P. Two NADPH oxidase isoforms are required for sexual reproduction and ascospore germination in the filamentous fungus Podospora anserina. Fungal Genet. Biol. 2004, 41, 982-997. [CrossRef]

41. Latgé, J.P. Aspergillus fumigatus and aspergillosis. Clin. Microbiol. Rev. 1999, 12, 310-350. [CrossRef]

42. Kurucz, V.; Krüger, T.; Antal, K.; Dietl, A.M.; Haas, H.; Pócsi, I.; Kniemeyer, O.; Emri, T. Additional oxidative stress reroutes the global response of Aspergillus fumigatus to iron depletion. BMC Genom. 2018, 19, 357. [CrossRef] [PubMed]

43. Lambou, K.; Lamarre, C.; Beau, R.; Dufour, N.; Latge, J.P. Functional analysis of the superoxide dismutase family in Aspergillus fumigatus. Mol. Microbiol. 2010, 75, 910-923. [CrossRef] 
44. Culotta, V.C. Superoxide dismutase, oxidative stress, and cell metabolism. Curr. Top. Cell. Regul. 2001, 36, 117-132. [CrossRef]

45. Du, W.; Zhai, P.; Liu, S.; Zhang, Y.; Lua, L. The copper chaperone CcsA, coupled with superoxide dismutase SodA, mediates the oxidative stress response in Aspergillus fumigatus. Appl. Environ. Microbiol. 2021, 87,1-16. [CrossRef]

46. Rementeria, A.; López-Molina, N.; Ludwig, A.; Vivanco, A.B.; Bikandi, J.; Pontón, J.; Garaizar, J. Genes and molecules involved in Aspergillus fumigatus virulence. Rev. Iberoam. Micol. 2005, 22, 1-23. [CrossRef]

47. Kim, Y.; Heo, I.B.; Yu, J.H.; Shin, K.S. Characteristics of a regulator of G-protein signaling (RGS) rgsC in Aspergillus fumigatus. Front. Microbiol. 2017, 8, 2058. [CrossRef] [PubMed]

48. Oberegger, H.; Zadra, I.; Schoeser, M.; Haas, H. Iron starvation leads to increased expression of Cu/Zn-superoxide dismutase in Aspergillus. FEBS Lett. 2000, 485, 113-116. [CrossRef]

49. Dlouhy, A.C.; Outten, C.E. The iron metallome in Eukaryotic organisms. Met. Ions Life Sci. 2013, 12, 241-278. [CrossRef]

50. Holdom, M.D.; Lechenne, B.; Hay, R.J.; Hamilton, A.J.; Monod, M. Production and characterization of recombinant Aspergillus fumigatus $\mathrm{Cu}, \mathrm{Zn}$ superoxide dismutase and its recognition by immune human sera. J. Clin. Microbiol. 2000, 38, 558-562. [CrossRef] [PubMed]

51. Amaike, S.; Keller, N.P. Aspergillus flavus. Annu. Rev. Phytopathol. 2011, 49, 107-133. [CrossRef]

52. Madhyastha, M.S.; Bhat, R.V. Aspergillus parasiticus growth and aflatoxin production on black and white pepper and the inhibitory action of their chemical constituents. Appl. Environ. Microbiol. 1984, 48, 376-379. [CrossRef]

53. Lee, S.E.; Mahoney, N.E.; Campbell, B.C. Inhibition of aflatoxin B1 biosynthesis by piperlongumine isolated from Piper longum L. J. Microbiol. Biotechnol. 2002, 12, 679-682.

54. Caceres, I.; El Khoury, R.; Bailly, S.; Oswald, I.P.; Puel, O.; Bailly, J.D. Piperine inhibits aflatoxin B1 production in Aspergillus flavus by modulating fungal oxidative stress response. Fungal Genet. Biol. 2017, 107, 77-85. [CrossRef]

55. Narasaiah, K.V.; Sashidhar, R.B.; Subramanyam, C. Biochemical analysis of oxidative stress in the production of aflatoxin and its precursor intermediates. Mycopathologia 2006, 162, 179-189. [CrossRef]

56. Fountain, J.C.; Scully, B.T.; Chen, Z.Y.; Gold, S.E.; Glenn, A.E.; Abbas, H.K.; Lee, R.D.; Kemerait, R.C.; Guo, B. Effects of hydrogen peroxide on different toxigenic and atoxigenic isolates of Aspergillus flavus. Toxins 2015, 7, 2985-2999. [CrossRef]

57. Fountain, J.C.; Koh, J.; Yang, L.; Pandey, M.K.; Nayak, S.N.; Bajaj, P.; Zhuang, W.J.; Chen, Z.Y.; Kemerait, R.C.; Lee, R.D.; et al. Proteome analysis of Aspergillus flavus isolate-specific responses to oxidative stress in relationship to aflatoxin production capability. Sci. Rep. 2018, 8, 3430. [CrossRef] [PubMed]

58. Zaccaria, M.; Ludovici, M.; Sanzani, S.M.; Ippolito, A.; Cigliano, R.A.; Sanseverino, W.; Scarpari, M.; Scala, V.; Fanelli, C.; Reverberi, M. Menadione-induced oxidative stress re-shapes the oxylipin profile of Aspergillus flavus and its lifestyle. Toxins 2015, 7, 4315-4329. [CrossRef]

59. Furukawa, T.; Sakuda, S. Inhibition of aflatoxin production by paraquat and external superoxide dismutase in Aspergillus flavus Toxins 2019, 11, 107. [CrossRef] [PubMed]

60. Tian, P.P.; Lv, Y.Y.; Lv, A.; Yuan, W.J.; Zhang, S.B.; Li, N.; Hu, Y. Sen Antifungal effects of fusion puroindoline B on the surface and intracellular environment of Aspergillus flavus. Probiotics Antimicrob. Proteins 2021, 13, 249-260. [CrossRef] [PubMed]

61. Devi, M.S.; Sashidhar, R.B. Antiaflatoxigenic effects of selected antifungal peptides. Peptides 2019, 115, 15-26. [CrossRef]

62. Reverberi, M.; Punelli, M.; Scala, V.; Scarpari, M.; Uva, P.; Mentzen, W.I.; Dolezal, A.L.; Woloshuk, C.; Pinzari, F.; Fabbri, A.A.; et al. Genotypic and phenotypic versatility of Aspergillus flavus during maize exploitation. PLoS ONE 2013, 8, e68735. [CrossRef] [PubMed]

63. Gross-Steinmeyer, K.; Eaton, D.L. Dietary modulation of the biotransformation and genotoxicity of aflatoxin B1. Toxicology 2012, 299, 69-79. [CrossRef] [PubMed]

64. Kenne, G.J.; Gummadidala, P.M.; Omebeyinje, M.H.; Mondal, A.M.; Bett, D.K.; McFadden, S.; Bromfield, S.; Banaszek, N.; Velez-Martinez, M.; Mitra, C.; et al. Activation of aflatoxin biosynthesis alleviates total ROS in Aspergillus parasiticus. Toxins 2018, 10, 57. [CrossRef] [PubMed]

65. Lass-Flörl, C.; Griff, K.; Mayr, A.; Petzer, A.; Gastl, G.; Bonatti, H.; Freund, M.; Kropshofer, G.; Dierich, M.P.; Nachbaur, D Epidemiology and outcome of infections due to Aspergillus terreus: 10-Year single centre experience. Br. J. Haematol. 2005, 131, 201-207. [CrossRef]

66. Jukic, E.; Blatzer, M.; Posch, W.; Steger, M.; Binder, U.; Lass-Flörl, C.; Wilflingseder, D. Oxidative stress response tips the balance in Aspergillus terreus amphotericin B resistance. Antimicrob. Agents Chemother. 2017, 61, e00670-17. [CrossRef]

67. Leiter, E.; Park, H.S.; Kwon, N.J.; Han, K.H.; Emri, T.; Olah, V.; Meszaros, I.; Dienes, B.; Vincze, J.; Csernoch, L.; et al. Characterization of the aodA, dnmA, mnSOD and pimA genes in Aspergillus nidulans. Sci. Rep. 2016, 6, 20523. [CrossRef]

68. Hubka, V.; Kolařík, M.; Kubátová, A.; Peterson, S.W. Taxonomic revision of Eurotium and transfer of species to Aspergillus. Mycologia 2013, 105, 912-937. [CrossRef] [PubMed]

69. Abrashev, R.; Feller, G.; Kostadinova, N.; Krumova, E.; Alexieva, Z.; Gerginova, M.; Spasova, B.; Miteva-Staleva, J.; Vassilev, S.; Angelova, M. Production, purification, and characterization of a novel cold-active superoxide dismutase from the Antarctic strain Aspergillus glaucus 363. Fungal Biol. 2016, 120, 679-689. [CrossRef] [PubMed]

70. Sun, X.; Zhou, X.; Cai, M.; Tao, K.; Zhang, Y. Identified biosynthetic pathway of aspergiolide A and a novel strategy to increase its production in a marine-derived fungus Aspergillus glaucus by feeding of biosynthetic precursors and inhibitors simultaneously. Bioresour. Technol. 2009, 100, 4244-4251. [CrossRef]

71. Bloomfield, G.; Pears, C. Superoxide signalling required for multicellular development of Dictyostelium. J. Cell Sci. 2003, 116, 3387-3397. [CrossRef] [PubMed] 
72. Soulère, L.; Delplace, P.; Davioud-Charvet, E.; Py, S.; Sergheraert, C.; Périé, J.; Ricard, I.; Hoffmann, P.; Dive, D. Screening of Plasmodium falciparum iron superoxide dismutase inhibitors and accuracy of the SOD-assays. Bioorg. Med. Chem. 2003, 11, 4941-4944. [CrossRef]

73. Samarawickrema, N.A.; Brown, D.M.; Upcroft, J.A.; Thammapalerd, N.; Upcroft, P. Involvement of superoxide dismutase and pyruvate: Ferredoxin oxidoreductase in mechanisms of metronidazole resistance in Entamoeba histolytica. J. Antimicrob. Chemother. 1997, 40, 833-840. [CrossRef] [PubMed]

74. Wassmann, C.; Hellberg, A.; Tannich, E.; Bruchhaus, I. Metronidazole resistance in the protozoan parasite Entamoeba histolytica is associated with increased expression of iron-containing superoxide dismutase and peroxiredoxin and decreased expression of ferredoxin 1 and flavin reductase. J. Biol. Chem. 1999, 274, 26051-26056. [CrossRef]

75. Raj, D.; Ghosh, E.; Mukherjee, A.K.; Nozaki, T.; Ganguly, S. Differential gene expression in Giardia lamblia under oxidative stress: Significance in eukaryotic evolution. Gene 2014, 535, 131-139. [CrossRef]

76. Tekwani, B.L.; Mehlotra, R.K. Molecular basis of defence against oxidative stress in Entamoeba histolytica and Giardia lamblia Microbes Infect. 1999, 1, 385-394. [CrossRef]

77. Murray, P.R.; Rosenthal, K.S.; Pfaller, M.A. Medical Microbiology, 9th ed.; Elsevier Health Sciences, 2020; ISBN 032367450X. Available online: https://books.google.co.kr/books?hl=zh-CN\&lr=\&id=JN_SDwAAQBAJ\&oi=fnd\&pg=PP1\&dq=Murray, +P R.\%3B+Rosenthal,+K.S.\%3B+Pfaller, +M.A.+Medical+Microbiology, +9 th+ed. $\% 3 \mathrm{~B}+$ Elsevier+Health+Sciences\&ots=KTHCd4P9 8r\&sig=HdnFVT8py1WgVp0w8xv-3MJePN0\&redir_esc=y\#v=onepage\&q\&f=false (accessed on 23 June 2021).

78. Molyneux, D. Neglected Tropical Diseases. Available online: https:/ /www.who.int/health-topics/neglected-tropical-diseases\# tab=tab_1 (accessed on 3 December 2021).

79. Desquesnes, M.; Holzmuller, P.; Lai, D.H.; Dargantes, A.; Lun, Z.R.; Jittaplapong, S. Trypanosoma evansi and surra: A review and perspectives on origin, history, distribution, taxonomy, morphology, hosts, and pathogenic effects. Biomed. Res. Int. 2013, 2013, 194176. [CrossRef] [PubMed]

80. Gardiner, P.R.; Wilson, A.J. Trypanosoma (Duttonefla) vivax. Parasitol. Today 1987, 3, 49-52. [CrossRef]

81. Ooi, C.P.; Schuster, S.; Cren-Travaillé, C.; Bertiaux, E.; Cosson, A.; Goyard, S.; Perrot, S.; Rotureau, B. The cyclical development of Trypanosoma vivax in the tsetse fly involves an asymmetric division. Front. Cell. Infect. Microbiol. 2016, 6, 115. [CrossRef]

82. Fairlamb, A.H.; Cerami, A. Metabolism and functions of trypanothione in the kinetoplastida. Annu. Rev. Microbiol. 1992, 46, 695-729. [CrossRef] [PubMed]

83. Horáková, E.; Faktorová, D.; Kraeva, N.; Kaur, B.; Van Den Abbeele, J.; Yurchenko, V.; Lukeš, J. Catalase compromises the development of the insect and mammalian stages of Trypanosoma brucei. FEBS J. 2020, 287, 964-977. [CrossRef]

84. Martínez, A.; Prolo, C.; Estrada, D.; Rios, N.; Alvarez, M.N.; Piñeyro, M.D.; Robello, C.; Radi, R.; Piacenza, L. Cytosolic Fesuperoxide dismutase safeguards Trypanosoma cruzi from macrophage-derived superoxide radical. Proc. Natl. Acad. Sci. USA 2019, 116, 8879-8888. [CrossRef] [PubMed]

85. Quiñones, W.; Acosta, H.; Gonçalves, C.S.; Motta, M.C.M.; Gualdrón-López, M.; Michels, P.A.M. Structure, properties, and function of glycosomes in Trypanosoma cruzi. Front. Cell. Infect. Microbiol. 2020, 10, 25. [CrossRef] [PubMed]

86. Temperton, N.J.; Wilkinson, S.R.; Kelly, J.M. Cloning of an Fe-superoxide dismutase gene homologue from Trypanosoma cruzi. Mol. Biochem. Parasitol. 1996, 76, 339-343. [CrossRef]

87. Ismail, S.O.; Paramchuk, W.; Skeiky, Y.A.W.; Reed, S.G.; Bhatia, A.; Gedamu, L. Molecular cloning and characterization of two iron superoxide dismutase cDNAs from Trypanosoma cruzi. Mol. Biochem. Parasitol. 1997, 86, 187-197. [CrossRef]

88. Mateo, H.; Marín, C.; Pérez-Cordón, G.; Sánchez-Moreno, M. Purification and biochemical characterization of four iron superoxide dismutases in Trypanosoma cruzi. Mem. Inst. Oswaldo Cruz 2008, 103, 271-276. [CrossRef]

89. Martinez, A.; Prolo, C.; Estrada, D.; Rios, N.; Piñeyro, D.; Robello, C.; Radi, R.; Piacenza, L. P-162-Cytosolic Fe-superoxide dismutase protects Trypanosoma cruzi from macrophage-derived superoxide radical increasing pathogen virulence in vivo. Free Radic. Biol. Med. 2018, 120, S93. [CrossRef]

90. Paula, J.I.O.; da Pinto, J.S.; Rossini, A.; Nogueira, N.P.; Paes, M.C. New perspectives for hydrogen peroxide in the amastigogenesis of Trypanosoma cruzi in vitro. Biochim. Biophys. Acta Mol. Basis Dis. 2020, 1866, 165951. [CrossRef]

91. Estrada, D.; Specker, G.; Martínez, A.; Dias, P.P.; Hissa, B.; Andrade, L.O.; Radi, R.; Piacenza, L. Cardiomyocyte diffusible redox mediators control Trypanosoma cruzi infection: Role of parasite mitochondrial iron superoxide dismutase. Biochem. J. 2018, 475, 1235-1251. [CrossRef]

92. Beltran-Hortelano, I.; Perez-Silanes, S.; Galiano, S. Trypanothione reductase and superoxide dismutase as current drug targets for Trypanosoma cruzi: An overview of compounds with activity against chagas disease. Curr. Med. Chem. 2017, 24, 1066-1138. [CrossRef]

93. Nogueira, F.B.; Krieger, M.A.; Nirdé, P.; Goldenberg, S.; Romanha, A.J.; Murta, S.M.F. Increased expression of iron-containing superoxide dismutase-A (TcFeSOD-A) enzyme in Trypanosoma cruzi population with in vitro-induced resistance to benznidazole. Acta Trop. 2006, 100, 119-132. [CrossRef]

94. Quebrada Palacio, L.P.; González, M.N.; Hernandez-Vasquez, Y.; Perrone, A.E.; Parodi-Talice, A.; Bua, J.; Postan, M. Phenotypic diversity and drug susceptibility of Trypanosoma cruzi TcV clinical isolates. PLoS ONE 2018, 13, e0203462. [CrossRef]

95. Olmo, F.; Clares, M.P.; Marín, C.; González, J.; Inclán, M.; Soriano, C.; Urbanová, K.; Tejero, R.; Rosales, M.J.; Krauth-Siegel, R.L.; et al. Synthetic single and double aza-scorpiand macrocycles acting as inhibitors of the antioxidant enzymes iron superoxide 
dismutase and trypanothione reductase in Trypanosoma cruzi with promising results in a murine model. RSC Adv. 2014, 4, 65108-65120. [CrossRef]

96. Sanz, A.M.; Gómez-Contreras, F.; Navarro, P.; Sánchez-Moreno, M.; Boutaleb-Charki, S.; Campuzano, J.; Pardo, M.; Osuna, A.; Cano, C.; Yunta, M.J.R.; et al. Efficient inhibition of iron superoxide dismutase and of Trypanosoma cruzi growth by benzo[g]phthalazine derivatives functionalized with one or two imidazole rings. J. Med. Chem. 2008, 51, 1962-1966. [CrossRef]

97. Puente, V.; Laurella, L.C.; Spina, R.M.; Lozano, E.; Martino, V.S.; Sosa, M.A.; Sülsen, V.P.; Lombardo, E. Primary targets of the sesquiterpene lactone deoxymikanolide on Trypanosoma cruzi. Phytomedicine 2019, 56, 27-34. [CrossRef]

98. Martín-Escolano, R.; Martín-Escolano, J.; Ballesteros-Garrido, R.; Cirauqui, N.; Abarca, B.; Rosales, M.J.; Sánchez-Moreno, M.; Ballesteros, R.; Marín, C. Repositioning of leishmanicidal [1,2,3]Triazolo[1,5-a]pyridinium salts for Chagas disease treatment: Trypanosoma cruzi cell death involving mitochondrial membrane depolarisation and Fe-SOD inhibition. Parasitol. Res. 2020, 119, 2943-2954. [CrossRef]

99. Concha-Valdez, F.; Marín, C.; Cañas-Ruíz, R.; Sosa-Matú, C.; EScobedo-Ortegón, J.; Martín-Montes, A.; Olmo, F.; Sánchez-Moreno, M. Detection of anti-Trypanosoma cruzi antibodies among donors at a blood bank from southern Mexico, using an iron superoxide dismutase excreted (Fe-Sode) as antigen. J. Immunol. Infect. Dis. 2017, 4, 103. [CrossRef]

100. Villagrán, M.E.; Marín, C.; Rodríguez-Gonzalez, I.; De Diego, J.A.; Sánchez-Moreno, M. Use of an iron superoxide dismutase excreted by Trypanosoma cruzi in the diagnosis of chagas disease: Seroprevalence in rural zones of the state of Queretaro, Mexico. Am. J. Trop. Med. Hyg. 2005, 73, 510-516. [CrossRef] [PubMed]

101. López-Cespedes, A.; Longoni, S.S.; Sauri-Arceo, C.H.; Rodríguez-Vivas, R.I.; Villegas, N.; Escobedo-Ortegón, J.; Barrera-Pérez, M.A.; Sánchez-Moreno, M.; Bolio González, M.E.; Marín, C. Seroprevalence of antibodies against the excreted antigen superoxide dismutase by Trypanosoma cruzi in dogs from the Yucatan Peninsula (Mexico). Zoonoses Public Health 2013, 60, 277-283. [CrossRef]

102. Longoni, S.S.; Marín, C.; Sauri-Arceo, C.H.; López-Cespedes, A.; Rodríguez-Vivas, R.I.; Villegas, N.; Escobedo-Ortegón, J.; BarreraPérez, M.A.; Bolio-Gonzalez, M.E.; Sánchez-Moreno, M. An iron-superoxide dismutase antigen-based serological screening of dogs indicates their potential role in the transmission of cutaneous leishmaniasis and trypanosomiasis in Yucatan, Mexico. Vector-Borne Zoonotic Dis. 2011, 11, 815-821. [CrossRef] [PubMed]

103. Longoni, S.S.; López-Cespedes, A.; Sánchez-Moreno, M.; Bolio-Gonzalez, M.E.; Sauri-Arceo, C.H.; Rodríguez-Vivas, R.I.; Marín, C. Detection of different Leishmania spp. and Trypanosoma cruzi antibodies in cats from the Yucatan Peninsula (Mexico) using an iron superoxide dismutase excreted as antigen. Comp. Immunol. Microbiol. Infect. Dis. 2012, 35, 469-476. [CrossRef]

104. Arjona, J.G.; Zaragoza, V.M.; Zaragoza, V.C.; García Herrera, R.; Sánchez, M.M.; Santamaria, M.E.; Cruz, B.L. Antibodies of Trypanosoma cruzi, Leishmania mexicana and Leishmania braziliensis in domiciled dogs in Tabasco, Mexico. Rev. MVZ Córdoba 2017, 22, 5829-5836. [CrossRef]

105. Wilkinson, S.R.; Prathalingam, S.R.; Taylor, M.C.; Ahmed, A.; Horn, D.; Kelly, J.M. Functional characterisation of the iron superoxide dismutase gene repertoire in Trypanosoma brucei. Free Radic. Biol. Med. 2006, 40, 198-209. [CrossRef]

106. Dufernez, F.; Yernaux, C.; Gerbod, D.; Noël, C.; Chauvenet, M.; Wintjens, R.; Edgcomb, V.P.; Capron, M.; Opperdoes, F.R.; Viscogliosi, E. The presence of four iron-containing superoxide dismutase isozymes in Trypanosomatidae: Characterization, subcellular localization, and phylogenetic origin in Trypanosoma brucei. Free Radic. Biol. Med. 2006, 40, 210-225. [CrossRef]

107. Prathalingham, S.R.; Wilkinson, S.R.; Horn, D.; Kelly, J.M. Deletion of the Trypanosoma brucei superoxide dismutase gene sodb1 increases sensitivity to nifurtimox and benznidazole. Antimicrob. Agents Chemother. 2007, 51, 755-758. [CrossRef] [PubMed]

108. Ogunleye, O.O.; Jatau, I.D.; Natala, A.J.; Ola-Fadunsin, S.D. Effects of aqueous extract of fruit pulp of Adansonia digitata L. on the oxidative stress profile against Trypanosoma brucei brucei infection in albino rats. Clin. Phytosci. 2020, 6, 57. [CrossRef]

109. Sheneni, V.D.; Odiba, V.A.; Idih, F.M. Effect of administration of zinc and selenium on lipid peroxidation and endogenous antioxidant enzymes in Trypanosoma brucei infected albino rats. Open Access J. Sci. 2018, 2, 383-387. [CrossRef]

110. Edoga, C.O.; Wopara, I.; Anukwuorji, C.A.; Ani, E.C.; Eneje, V.O. Effect of $\alpha$-tocopherol on the antioxidant enzymes of male wistar albino rats infected with Trypanosoma brucei brucei. Manila J. Sci. 2020, 13, 109-119.

111. Steverding, D.; Kolosevska, K.; Sánchez-Moreno, M. Trypanocidal activity of tetradentated pyridine-based manganese complexes is not linked to inactivation of superoxide dismutase. Exp. Parasitol. 2018, 192, 1-5. [CrossRef] [PubMed]

112. Kabiri, M.; Steverding, D. Identification of a developmentally regulated iron superoxide dismutase of Trypanosoma brucei. Biochem. J. 2001, 360, 173-177. [CrossRef]

113. Marciano-Cabral, F.; Cabral, G. Acanthamoeba spp. as agents of disease in humans. Clin. Microbiol. Rev. 2003, 16, 273-307. [CrossRef]

114. Lorenzo-Morales, J.; Khan, N.A.; Walochnik, J. An update on Acanthamoeba keratitis diagnosis, pathogenesis and treatment. Parasite 2015, 22, 10. [CrossRef] [PubMed]

115. Lorenzo-Morales, J.; Martín-Navarro, C.M.; López-Arencibia, A.; Arnalich-Montiel, F.; Piñero, J.E.; Valladares, B. Acanthamoeba keratitis: An emerging disease gathering importance worldwide? Trends Parasitol. 2013, 29, 181-187. [CrossRef] [PubMed]

116. Siddiqui, R.; Khan, N.A. Acanthamoeba is an evolutionary ancestor of macrophages: A myth or reality? Exp. Parasitol. 2012, 130, 95-97. [CrossRef] [PubMed]

117. Choi, D.-H.; Na, B.-K.; Seo, M.-S.; Song, H.-R.; Song, C.-Y. Purification and characterization of iron superoxide dismutase and copper-zinc superoxide dismutase from Acanthamoeba castellanii. J. Parasitol. 2000, 86, 899-907. [CrossRef]

118. Dao, O.; Asaithambi, K.; Na, B.K.; Lee, K.H. Crystal structure of an iron superoxide dismutase from the pathogenic amoeba Acanthamoeba castellanii. Acta Crystallogr. Sect. F 2019, 75, 480-488. [CrossRef] 
119. Czarna, M.; Sluse, F.E.; Jarmuszkiewicz, W. Mitochondrial function plasticity in Acanthamoeba castellanii during growth in batch culture. J. Bioenerg. Biomembr. 2007, 39, 149-157. [CrossRef]

120. Davies, B.; Chattings, L.S.; Edwards, S.W. Superoxide generation during phagocytosis by Acanthamoeba castellanii: Similarities to the respiratory burst of immune phagocytes. J. Gen. Microbiol. 1991, 137, 705-710. [CrossRef]

121. Brooks, S.E.; Schneider, D.L. Oxidative metabolism associated with phagocytosis in Acanthamoeba castellanii. J. Protozool. 1985, 32, 330-333. [CrossRef]

122. Anderson, I.J.; Watkins, R.F.; Samuelson, J.; Spencer, D.F.; Majoros, W.H.; Gray, M.W.; Loftus, B.J. Gene discovery in the Acanthamoeba castellanii genome. Protist 2005, 156, 203-214. [CrossRef]

123. Shabardina, V.; Kischka, T.; Kmita, H.; Suzuki, Y.; Makałowski, W. Environmental adaptation of Acanthamoeba castellanii and Entamoeba histolytica at genome level as seen by comparative genomic analysis. Int. J. Biol. Sci. 2018, 14, 306-320. [CrossRef] [PubMed]

124. Kim, J.Y.; Na, B.K.; Song, K.J.; Park, M.H.; Park, Y.K.; Kim, T.S. Functional expression and characterization of an ironcontaining superoxide dismutase of Acanthamoeba castellanii. Parasitol. Res. 2012, 111, 1673-1682. [CrossRef] [PubMed]

125. Hadaś, E.; Mazur, T. Biochemical markers of pathogenicity and virulence of Acanthamoeba sp. strains. Parasitol. Res. 1993, 79, 696-698. [CrossRef] [PubMed]

126. Koltover, K.V. Free radical timer of aging: From chemistry of free radicals to systems theory of reliability. Curr. Aging Sci. 2016, 10, 12-17. [CrossRef]

127. Hekimi, S.; Lapointe, J.; Wen, Y. Taking a "good" look at free radicals in the aging process. Trends Cell Biol. 2011, 21, 569-576. [CrossRef]

128. Apel, K.; Hirt, H. Reactive oxygen species: Metabolism, oxidative stress, and signal transduction. Annu. Rev. Plant Biol. 2004, 55, 373-399. [CrossRef]

129. Fischer, F.; Hamann, A.; Osiewacz, H.D. Mitochondrial quality control: An integrated network of pathways. Trends Biochem. Sci. 2012, 37, 284-292. [CrossRef] [PubMed]

130. Dan Dunn, J.; Alvarez, L.A.J.; Zhang, X.; Soldati, T. Reactive oxygen species and mitochondria: A nexus of cellular homeostasis. Redox Biol. 2015, 6, 472-485. [CrossRef] [PubMed]

131. Sies, H. Hydrogen peroxide as a central redox signaling molecule in physiological oxidative stress: Oxidative eustress. Redox Biol. 2017, 11, 613-619. [CrossRef] [PubMed]

132. Kochevar, I.E. Singlet oxygen signaling: From intimate to global. Sci. STKE 2004, 2004, pe7. [CrossRef]

133. Ullrich, V.; Brüne, B.; Hecker, G.; Schmidt, K.U.; Mülsch, A.; Busse, R. Physiological targets of superoxide anion and hydrogen peroxide in reperfusion injury. Free Radic. Res. Commun. 1989, 7, 265-274. [CrossRef]

134. Egwu, C.O.; Augereau, J.-M.; Reybier, K.; Benoit-Vical, F. Reactive oxygen species as the brainbox in malaria treatment. Antioxidants 2021, 10, 1872. [CrossRef]

135. Dincel, G.C.; Atmaca, H.T. Role of oxidative stress in the pathophysiology of Toxoplasma gondii infection. Int. J. Immunopathol. Pharmacol. 2016, 29, 226-240. [CrossRef]

136. Peraza, L.; Hansberg, W. Neurospora crassa catalases, singlet oxygen and cell differentiation. Biol. Chem. 2002, 383, 569-575. [CrossRef]

137. Díez, B.; Schleissner, C.; Moreno, M.A.; Rodríguez, M.; Collados, A.; Barredo, J.L. The manganese superoxide dismutase from the penicillin producer Penicillium chrysogenum. Curr. Genet. 1998, 33, 387-394. [CrossRef] [PubMed]

138. Lopes, M.; Mota, M.; Belo, I. Comparison of Yarrowia lipolytica and Pichia pastoris cellular response to different agents of oxidative stress. Appl. Biochem. Biotechnol. 2013, 170, 448-458. [CrossRef] [PubMed]

139. Jeong, J.H.; Kwon, E.S.; Roe, J.H. Characterization of the manganese-containing superoxide dismutase and its gene regulation in stress response of Schizosaccharomyces pombe. Biochem. Biophys. Res. Commun. 2001, 283, 908-914. [CrossRef] [PubMed]

140. Dirschnabel, D.E.; Nowrousian, M.; Cano-Domínguez, N.; Aguirre, J.; Teichert, I.; Kück, U. New insights into the roles of NADPH oxidases in sexual development and ascospore germination in Sordaria macrospora. Genetics 2014, 196, 729-744. [CrossRef]

141. Carmona-Gutierrez, D.; Bauer, M.A.; Zimmermann, A.; Aguilera, A.; Austriaco, N.; Ayscough, K.; Balzan, R.; Bar-Nun, S.; Barrientos, A.; Belenky, P.; et al. Guidelines and recommendations on yeast cell death nomenclature. Microb. Cell 2018, 5, 4-31. [CrossRef] [PubMed]

142. Minina, E.A.; Staal, J.; Alvarez, V.E.; Berges, J.A.; Berman-Frank, I.; Beyaert, R.; Bidle, K.D.; Bornancin, F.; Casanova, M.; Cazzulo, J.J.; et al. Classification and nomenclature of metacaspases and paracaspases: No more confusion with caspases. Mol. Cell 2020, 77, 927-929. [CrossRef]

143. Klionsky, D.J.; Cregg, J.M.; Dunn, W.A.; Emr, S.D.; Sakai, Y.; Sandoval, I.V.; Sibirny, A.; Subramani, S.; Thumm, M.; Veenhuis, M.; et al. A unified nomenclature for yeast autophagy-related genes. Dev. Cell 2003, 5, 539-545. [CrossRef] 